\title{
Work capacity, sociodemographic and work characteristics of nurses at a university hospital
}

\author{
Eunice Fabiani Hilleshein ${ }^{1}$
}

Liana Lautert $^{2}$

This cross-sectional study evaluated the work capacity of 195 nurses at a university hospital, from a calculation of sample size with a Confidence Interval (CI) of 95\%. The data was collected by means of the Work Capacity Index (WCI) instrument and analyzed by statistical analysis. 94.5\% of the sample was made up of women; the average age was of 42.6 years $(s d=8.5) ; 66.5 \%$ had partners and $76.7 \%$ were educated to post-graduate level. $36.0 \%$ worked the night shift; $28.4 \%$ the morning shift and $20.8 \%$ the afternoon shift. The average score given to work capacity was Good (41.8 points) and there was a significant correlation with pay ( $p$-value<0.05), satisfaction with workplace $(p$-value $=0.001)$ and feeling valued by the institution $(p$-value $=0.003)$. The group which carried out family activities showed higher scores in the WCI compared to those who did not $(p$-value $=0.009)$. The nurses presented differing sociodemographic and work aspects, with a high capacity for work.

Descriptors: Occupational Health; Work Capacity Evaluation; Nurses.

${ }^{1}$ RN MSc.

2 PhD, Associate Professor, Universidade Federal do Rio Grande do Sul, Brazil. 


\section{Capacidade para o trabalho, características sociodemográficas e laborais de enfermeiros de um hospital universitário}

O estudo transversal avaliou a capacidade para o trabalho de 195 enfermeiros de um hospital universitário, a partir do cálculo amostral com IC de 95\%. Os dados foram coletados por meio do instrumento Índice de Capacidade para o Trabalho (ICT) e analisados por estatística analítica, sendo que $94,5 \%$ da amostra era composta por mulheres com idade média de $42,6$ anos ( $d p=8,5), 66,5 \%$ com companheiros e 76,7\% tinham pós-graduação. Quanto ao turno de trabalho, 36\% atuava à noite; $28,4 \%$ pela manhã e $20,8 \%$ à tarde. O escore médio de capacidade para o trabalho foi Bom (41,8 pontos) e houve correlação significativa com a remuneração ( $p$-valor<0,05), satisfação com o local de trabalho ( $p$-valor=0,001), valorização por parte da instituição ( $p$-valor=0,003). E o grupo que realiza programas em família apresentou escores superiores no ICT aos daqueles que não as realizam ( $p$-valor=0,009). Os enfermeiros apresentaram aspectos sociodemográficos e laborais diferenciados, com elevada capacidade para o trabalho.

Descritores: Saúde do Trabalhador; Avaliação da Capacidade de Trabalho; Enfermeiras.

\section{Capacidad de trabajo, características sociodemográficas y laborales de las enfermeras de un hospital universitario.}

El estudio transversal evaluó la capacidad de 195 enfermeras que trabajan en un hospital universitario del cálculo de la muestra es del 95\%. Los datos fueron recogidos por el Índice de Instrumento Capacidad para el Trabajo y analizados por estadísticas y análisis y, 94,5\% de la muestra eran mujeres, edad media de 42,6 años ( $S D=8,5$ ), el $66,5 \%$ con los compañeros y $76,7 \%$ tiene un post-grado. El puntaje promedio de la capacidad de trabajo fue buena $(41,8$ puntos) y una correlación significativa con la remuneración $(p<0,05)$, satisfacción con el trabajo $(p=0,001)$, la recuperación por la institución $(p=0,003)$. $Y$ el grupo que lleva a cabo programas en las familias presentan puntuaciones superiores en las ICT a los que no las realizan $(p=0,009)$. Las enfermeras tenían diferentes aspectos de los cambios demográficos y laborales, con alta capacidad para el trabajo.

Descriptores: Salud laboral; Evaluación de Capacidad de Trabajo; Enfermeras.

\section{Introduction}

Current work conditions increasingly involve service provision and production models of accelerated and intensified speed, which determine the increase in productivity through a combination of work rhythm, the responsibility load, and the reduction of rest intervals during the work day - which leads to a progressive tendency for occupational risks, and can generate chronic effects on the workers' health and aging. To this one may add the discontent of some health care professionals, the result of the gap existing between the work system and their expectations in relation to work and quality of life ${ }^{(1)}$. For the worker under these conditions, work, which should be a source of fulfilment and recognition, can become a source of suffering and affect work capacity(2).
Work capacity is the principle of work-related well-being, and may be understood as the physical and mental capacity presented by the professional for execution of the tasks, based on the work's demands. A study carried out in Finland showed that work capacity does not remain satisfactory all through life, it being the case that some factors, such as the occupational environment and lifestyle, influence it strongly, in the most varied of work contexts ${ }^{(3)}$.

In health services generally and especially in the hospital environment, it may also be seen that the complexity of the work increases, due to various factors, among them the insertion of new technologies (hard, light-hard and light) and - in consequence - interpersonal 
relations. These changes in the productive field have raised questions inherent to the process of working in the health practices space, at the same time as the restructuring of care models is discussed - which refers to the organization of health services based on the realignment of expertise resulting from health professionals' actions, and their implications for work relations ${ }^{(4)}$.

In Nursing, in the same way, there has been restructuring in productive ways of meeting the work demands, resulting from the users' requirements and from the growing control of work processes. Thus, what the hospital health team does is complex, and involves different physical and mental demands which influence the health-illness binomial. This set of factors leads to anxiety, tension and suffering, which increases psychological burdens ${ }^{(5-6)}$.

In Brazil, attention to workers' health has been discussed with greater emphasis since the 80 s and 90s, when programs for Attention to Workers' Health were implanted in the health system, aimed at prevention, care and recuperation actions and at health promotion for workers. These impose social control as much in their planning as in the execution and evaluation of proposals and projects ${ }^{(7)}$.

Consequently, understanding how nurses perceive their work capacity can provide elements for planning programs for maintenance and improvement of aptitude for work among these professionals. It can also prevent harm to health resulting from work, and early retirement, which reduces social costs and has repercussions on quality of life, keeps people economically active and, further, allows the worker an active aging process.

Starting from the issue of workers' health, this investigation aims to evaluate capacity for work and describe the sociodemographic and work characteristics of nurses at a university hospital.

\section{Methods}

This is a cross-sectional investigation of a quantitative nature with data collected from a survey(8), with the application of a face-to-face questionnaire. The target population was nurses at the Clinical Hospital of Porto Alegre in Rio Grande do Sul.

Inclusion criteria for the sampling process were defined as follows: nurses contracted under the Consolidation of Labor Laws arrangement at least one year previously, with experience of the workplace, of both sexes, from all shifts and work units providing care activities. Nurses on sick leave, suspended or on holiday were excluded, along with senior managers. These last, being professors at the university, were not directly involved in care.

The study population was made up of 456 nurses, of whom 425 remained after the application of the inclusion and exclusion criteria. For estimating sample size, reliability of $95 \%$ was utilized, with a maximum margin of error in the proportion of $5 \%$. The application of these parameters for the sample calculation, carried out with the WinPepi software, version $1.31,2004$, produced a sample size of 195 nurses.

The research project was approved by the Research Committee of the Rio Grande do Sul Federal University School of Nursing and, later, by the Research Ethics Committee of the Clinical Hospital of Porto Alegre in Rio Grande do Sul (HCPA; no100.005).

The health professionals were approached at work, where the research was explained to them and they were invited to participate. There were 12 refusals, representing a rate of approximately $6 \%$, which is considered satisfactory for this form of research(9). Being research results, the refusals, like the missing (non-responses), were duly analyzed and dealt with through statistical techniques for analysis of missing responses (lost data), in line with the description of data.

Data collection was carried out through a selfapplied questionnaire which evaluated sociodemographic and work aspects, and the Work Capacity Index (WCI), which describes the worker's self-evaluation about work capacity ${ }^{(2)}$. The data was collected between $25^{\text {th }}$ June and $25^{\text {th }}$ August 2010, a period of 60 days altogether.

The scale which measures WCI was translated and adapted to Portuguese by researchers of the University of São Paulo in collaboration with other Brazilian universities and institutions ${ }^{(9)}$. The aspects evaluated by this scale permit the description of a general profile of work capacity and of functional capacity, and of factors which affect these. They may be used collectively or individually ${ }^{(3)}$. The way the worker's health appears demonstrates his or her work capacity. The evaluation of the WCI, through self-perceived health, offers information about the compromising of each worker's capacity in an isolated way, respecting peculiarities and allowing the offering of measures of support(3). The results may reach scores from 7 to 49 points, with 7 to 27 being classified as the group with low work capacity, 28 to 36 , having moderate work capacity, from 37 to 43 good work capacity, and from 44 to 49 , excellent work capacity ${ }^{(2)}$. From the scores obtained, the instrument proposes to explore measures used by the workers in their daily personal and work routines for overcoming stressors and keeping their work capacity at high levels. 
The data was processed with the Statistical Package for the Social Sciences ${ }^{\circledR}$ 15software and analyzed through descriptive statistics and inferential statistics. The WCI was evaluated through the Mann-Whitney and Kruskal Wallis tests for comparisons between groups. Also carried out were analyses for correlation between the WCI and the other quantitative variables, through Spearman's coefficiency correlation, with values of $\mathrm{p}<0.05$ being considered.

\section{Results}

The sample of 195 nurses was characterized as predominantly female $(94.5 \%)$ and $37.3 \%$ were in the age range of 40 to 49 years old.

Table 1 - Distribution of nurses in the Clinical Hospital of Porto Alegre, according to their sociodemographic characteristics. Porto Alegre, Rio Grande do Sul, Brazil, 2011

\begin{tabular}{|c|c|c|c|}
\hline Variable & $\%$ & $\begin{array}{c}\text { Margin of } \\
\text { error (95\%) }\end{array}$ & $\begin{array}{c}\mathrm{Cl} 95 \%(\mathrm{~N}) \\
\text { (LL;UL) }\end{array}$ \\
\hline \multicolumn{4}{|l|}{$\operatorname{Sex}(n=183)$} \\
\hline Female & 94.5 & 1.4 & $(395 ; 408)$ \\
\hline \multicolumn{4}{|l|}{ Age ranges $(n=177)$} \\
\hline Younger than 30 & 7.3 & 1.6 & $(24 ; 39)$ \\
\hline 30 to 39 years & 29.9 & 2.8 & $(115 ; 140)$ \\
\hline 40 to 49 years & 37.3 & 3.0 & $(145 ; 172)$ \\
\hline 50 years or over & 25.4 & 2.7 & $(96 ; 120)$ \\
\hline \multicolumn{4}{|l|}{ Marital status $(n=182)$} \\
\hline Married or with partner & 66.5 & 2.9 & $(270 ; 295)$ \\
\hline \multicolumn{4}{|l|}{ With children $(n=182)$} \\
\hline Yes & 66.5 & 2.9 & $(270 ; 295)$ \\
\hline \multicolumn{4}{|l|}{ Post-graduate qualification $(n=180)$} \\
\hline Yes & 76.7 & 2.6 & $(314 ; 337)$ \\
\hline \multicolumn{4}{|l|}{ Area of post-graduate qualification* } \\
\hline Care & 49.1 & 3.1 & $(195 ; 222)$ \\
\hline Management/Administration & 29.3 & 2.8 & $(112 ; 137)$ \\
\hline Teaching & 16.8 & 2.3 & $(61 ; 82)$ \\
\hline Other & 4.8 & 1.3 & $(14 ; 26)$ \\
\hline
\end{tabular}

Data source: HILLESHEIN, EF. Direct collection of data via questionnaire. (LL; UL): Lower Limit and Upper Limit estimated for the total population (N). *Multiple choice question
In relation to the nurses' work characteristics, $53.4 \%$ work in closed units and $44 \%$ in open units; $36.0 \%$ work at night, with rosters of 12 hours on, 36 hours off, $28.4 \%$ work mornings and $20.8 \%$ the afternoons. The afternoon shift included 'intermediate shift' nurses; this refers to workdays with hours differing from the traditional shifts, adopted in some hospitals. The intermediate shifts in the Clinical Hospital of Porto Alegre occur between $17: 30$ and 23:15 or between 19:00 and 01:15, are flexible and are determined according to the institution's work needs.

On a visual analog scale from zero to ten, the nurses' average satisfaction with pay was 6.5 ( $\mathrm{sd}=1.81$, median 7$)$ with a minimum of one and a maximum of ten.

The study demonstrated that $88.0 \%$ of the nurses have good or excellent work capacity. No examples of low work capacity were found.

There was a significant correlation $(p$-value $<0.05)$ of the WCI and the degree of satisfaction with pay, $(r=0.202)$.

Table 2 - Distribution of nurses in the Clinical Hospital of Porto Alegre, according to work characteristics. Porto Alegre, Rio Grande do Sul, Brazil, 2011

\begin{tabular}{lccc}
\hline \multicolumn{1}{c}{ Variable } & $\%$ & $\begin{array}{c}\text { Margin of } \\
\text { error (95\%) }\end{array}$ & $\begin{array}{c}\text { CI 95\% (N) } \\
\text { (LL;UL) }\end{array}$ \\
\hline Main function in the institution $(\mathrm{n}=180)$ & & & \\
Care & 92.8 & 1.6 & $(387 ; 402)$ \\
Administrative & 7.2 & 1.6 & $(23 ; 38)$ \\
If you feel satisfied with the area where you work ( $\mathrm{n}=183)$ & \\
$\quad$ Frequently & 87.4 & 2.1 & $(362 ; 381)$ \\
Sometimes & 11.5 & 2.0 & $(40 ; 58)$ \\
Rarely & 1.1 & 0.6 & $(2 ; 8)$ \\
If you feel valued by the institution $(\mathrm{n}=183)$ & & \\
$\quad$ Frequently & 56.8 & 3.1 & $(228 ; 255)$ \\
$\quad$ Sometimes & 37.2 & 3.0 & $(145 ; 171)$ \\
Rarely & 6.0 & 1.5 & $(19 ; 32)$ \\
I work in another institution( $\mathrm{n}=183)$ & & \\
Yes & 14.8 & 2.2 & $(53 ; 73)$ \\
No & 85.2 & 2.2 & $(353 ; 372)$ \\
\hline
\end{tabular}

Source of data: HILLESHEIN, EF. Data collected directly via questionnaire. (LL;UL): Lower Limit and Upper Limit estimated for total population (N).

Table 3 - Descriptive statistics of sociodemographic and work variables of the nurses at the Clinical Hospital of Porto Alegre. Porto Alegre, Rio Grande do Sul, Brazil, 2011

\begin{tabular}{|c|c|c|c|c|c|c|c|}
\hline & \multicolumn{3}{|c|}{$\mathbf{n}$} & \multirow{2}{*}{ CI 95\% (A) (LL;UL) } & \multirow{2}{*}{ Minimum } & \multirow{2}{*}{ Median } & \multirow{2}{*}{ Maximum } \\
\hline & Average & valid & Stan. Dev. & & & & \\
\hline Age (years) & 42.6 & 177 & 8.5 & $(41.4 ; 43.9)$ & 25.0 & 44.0 & 61.0 \\
\hline Length of training (years) & 18.0 & 168 & 8.4 & $(16.8 ; 19.3)$ & 3.0 & 18.0 & 34.0 \\
\hline Time worked in institution (years) & 14.2 & 182 & 9.3 & $(12.9 ; 15.7)$ & 0.8 & 13.3 & 33.0 \\
\hline Time worked on current shift (years) & 9.4 & 177 & 8.7 & $(8.1 ; 10.7)$ & 0.2 & 6.0 & 34.0 \\
\hline Time since last holidays (months) & 4.0 & 177 & 3.3 & $(3.5 ; 4.5)$ & 0.0 & 4.0 & 17.0 \\
\hline
\end{tabular}

Source of data: HILLESHEIN, EF. Data collected directly via questionnaire.

(LL;UL): Lower Limit and Upper Limit estimated for populational average (A). 
Table 4 - Percentage distribution of nurses according to categories of the Work Capacity Index. Porto Alegre, Rio Grande do Sul, Brazil, 2011

\begin{tabular}{lccc}
\hline WCI $(\mathbf{n = 1 8 3 )}$ & $\%$ & Margin of error $(95 \%)$ & Cl 95\% (N) (LL;UL) \\
\hline Moderate & 12.0 & 2.0 & $(42 ; 60)$ \\
Good & 47.6 & 3.1 & $(189 ; 216)$ \\
Excellent & 40.4 & 3.1 & $(158 ; 185)$ \\
\hline
\end{tabular}

Source of Data: HILLESHEIN, EF. Data collected directly via questionnaire. (LL;UL): Lower Limit and Upper Limit for the total population (M).

Table 5 - Correlation coefficient of the WCI of the nurses at the Clinical Hospital of Porto Alegre with the sociodemographic and work variables. Porto Alegre, Rio Grande do Sul, Brazil, 2011

\begin{tabular}{lcc}
\hline Variables & Correlation* $^{*}$ & p-value \\
\hline Age (years) & 0.002 & 0.978 \\
Length of training (years) & -0.032 & 0.681 \\
Time worked in institution (years) & 0.041 & 0.586 \\
Time worked on current shift (years) & 0.113 & 0.136 \\
Time since last holidays (months) & -0.039 & 0.604 \\
Degree of satisfaction with pay (\%) & 0.202 & 0.006 \\
\hline
\end{tabular}

Source of data: HILLESHEIN, EF. Data collected directly via questionnaire. *Spearman's Correlation Coefficient.

The average WCI score for the nurses was 41.8 points, $(s d=4.2)$ which was classified as good work capacity. A high average was also observed in these nurses' self-evaluation concerning their current work capacity compared with the 'lifetime's best' on a scale of 0 to 10 points $(8.6 \mathrm{sd}=1,1)$.

A comparison was carried out of the WCI of the nurses from various sociodemographic or work groups. In this analysis it was observed that the 'single or without partner' group had an average WCI of 42.31 , in relation to the 'married or with partner' group which obtained an average WCI score of $41.50(p=0.310)$. Also, there was no significant difference between the groups of nurses who had Good or Average scores.

As for lifestyle habits, it was observed that the group which carried out family activities showed a statistically significant difference $(p$-value $=0.009$ ) with an average WCI of 42.1 , superior to the group made up of those who did not carry out such experiences with family members (40.0).

Based on the correlation analysis, it was observed that feeling satisfied with one's workplace and feeling valued by the institution correlated positively in relation to the $\mathrm{WCI}$. In the same way, there was evidence of a statistically significant difference in the average WCI for the following variables: satisfaction with one's workplace ( $p$-value $=0.001)$, feeling of being valued by the institution ( $p$-value $=0.003$ ), and shift ( $p$-value=0.032).

As for illnesses and their relation with work capacity, only those with a medical diagnosis were analyzed, as recommended by the WCI instrument's authors. The study observed that the prevalent illnesses were, in decreasing order: musculo-skeletal, metabolic, respiratory, psychiatric and genito-urinary. Statistically significant differences in the WCI were only found in the following types of illness ( $p$-value $<0.05$ ); digestive illnesses (12.6\%), genito-urinary illnesses (5.5\%) and psychiatric illnesses $(14.8 \%)$, through multiple comparison techniques (Least Significance DifferenceLSD), with these being considered significant factors in reductions in the Work Capacity Index of nurses in the institution analyzed.

\section{Discussion}

This investigation permits the generalizing of results for the population of nurses of the university hospital in the study, in view of the fact that the sample was random and probabilistic, containing, therefore, all the units available for sampling in the population being considered.

The sociodemographic characterization of the nurses in the institution in the study resembles samples of nurses in other investigations. Different findings were found in a study which evaluated nursing workers in an Accident and Emergency unit in a public university hospital, where, with a mainly female sample $(74.1 \%)$, the average age was five years younger at 37.3 years, the prevalent age range being from 30 to 39 years $(44.4 \%)$ and the average WCI score slightly higher (42 points). There was, however, evidence of a functional loss in younger workers, with those younger than 35 having a WCI below 37 points $^{(10)}$.

Aging causes alterations in the organism and progressive losses of work capacity as age increases. At thirty, individuals attain the high point for intellectual, sensory and motor abilities, being able to reach excellence in their performance; adversity, however, can bring forward physical aging and affect work capacity ${ }^{(11)}$. This study found evidence that family activities, parties, trips out and get-togethers, on the other hand, affect work capacity in a positive way, and that the nurses who carry out these activities have an average WCI of 42.1, significantly higher than the group who do not carry out this type of activity $(p$-value $=0.009)$. Social support is identified as an 
element which reduces stress among nurses who work in hospital(12) and, as it seems, has a similar effect on the WCI score. The need for the family also appeared as a protective mechanism against illness, and as a step which supports the preservation of the individual's mental health(13). Thus, activities which support relationships should be stimulated and opportunities for them provided among nursing professionals. On the other hand, in this study, the WCI score was not influenced by whether or not an individual had a partner, or if they had children. Some investigations focus on the fact of having a partner or children and suggest that these individuals have an extra need with the family, even if they have employed a nanny(14). In addition, other studies have demonstrated that practising physical activities also reduces fatigue and increases work capacity, and that the consumption of alcoholic drinks reduces work capacity(15-16). These results reinforce the importance of workers developing healthy lifestyles so as to improve and maintain WCI scores.

It is important to emphasize that structural changes are ocurring in society, as people live more and more alone - the so-called single-person family. This does not necessarily leave them isolated, bearing in mind that they make use of various resources for building social relationships (such as the Internet), and live alone through choice, considering themselves happy in this condition ${ }^{(17)}$.

Nurses have increasingly sought further qualifications, with this study revealing that $76.7 \%$ have a post-graduate qualification. Even though no relationship was shown with the WCI score, professional qualifications may be reflected in improvements in patient care and confer visibility on the individuals and the institution, as they are guided to develop competencies.

From the point of view of level of education and specialization in Nursing, there is a tendency for intensive physical work to be substituted with more intellectual activities demanding specific knowledge. In the current work context, one may verify the need for workers who are qualified and able to take responsibility for increasingly complex and holistic processes ${ }^{(18)}$. For that, it is necessary to have a thorough command of the knowledge, which makes it possible to meet different demands, especially technological ones.

The shift which the nurse works has been identified in some investigations as a factor which interferes with the worker's social life, as it can create difficulties in planning one's own life, in balancing the relationship with partners and in finding time for one's children ${ }^{(14,19)}$. This study determined that the average WCI of nurses working afternoon or intermediate shifts (43.29) was higher than the averages of the morning and night shift groups (41.58), ( $p$-value=0.032). Another study, which evaluated fatigue and work capacity in fixed twelve hour shifts showed that the night shift workers had higher scores when compared to the others, a result attributed to better coping ${ }^{(20)}$ among the workers on this shift.

The majority of the nurses of the institution in the study do not have another job (85.2\%), which may have a positive effect on the high WCI scores. However, a study investigating unpaid work, carried out in the domestic, family area in a population of health care professionals, observed that this, coupled with a double workday, was responsible for a reduction in work capacity, and that the individuals had little time for themselves as a result of the excessive demands taken on ${ }^{(21)}$.

A study of information technology and telecommunication workers identified that the carrying out of at least one leisure activity per day reflected positively on WCI scores ${ }^{(22)}$. The authors of that study describe that if the worker maintains his work capacity and life capacity at high levels, after retirement he should have between 10 and 20 years of significant life ${ }^{(3)}$.

The fact that the majority of the subjects' work capacity was considered to be Good or Excellent does not exclude the necessity of its being promoted, maintained and improved, as the investigations revealed that work capacity worsens with age and length of service. Also, taking into account that people are remaining economically active for increasingly longer periods, it is necessary for strategies for attention to nurses' health to be devised, so as to maintain their work capacity and the active aging of these professionals.

As for health problems, osteomuscular alterations were prevalent in this group (37.7\%). However, it was the psychiatric, digestive and genito-urinary illnesses affecting the nurses $(14.8 \%, 12.6 \%$, and $5.5 \%$ respectively) which were associated with the WCI. The nurses with these conditions had low scores in the WCI, which did not show association with the satisfaction with the workplace or feelings of being valued by the institution. Thus, it may be inferred that work capacity can be related to the organization and to the demands imposed by the work ${ }^{(23)}$.

\section{Conclusion}

The Work Capacity Index questionnaire (WCI) may be utilized for individuals, when the aim is to check capacity and adopt specific support measures, or collectively, when the aim is to evaluate the work 
capacity of all the nurses, so as to identify the factors which affect group scores, with the aim of promoting comprehensive measures.

The nurses' average self-evaluation of current work capacity was high, compared to that of the 'lifetime's best' as well as compared to that of the WCI. These results had a relationship with satisfaction with workplace, pay, and a feeling of being valued by the institution, as well as with family activities, parties, trips and get-togethers, indicating that the current work conditions must be preserved and that social activities must be stimulated such as to favor the worker's capacity.

Among the study's limitations, it stands out that because it is a cross-sectional study, workers who were absent due to illness or accidents were not included, which might have influenced the results through the bias of healthy workers in the averages of the Work Capacity Index. Another limitation of this investigation is the method of data reporting through self-reporting, a procedure which can collect socially-acceptable responses. The study was able to demonstrate how the work process interferes in the worker's life. While some processes reduce work capacity, others increase it. Thus, when reductive work processes are present, they foster the appearance of illnesses, early aging and loss of work capacity. When health is valued, however, and the elements which favor quality of life are present and strengthened, they promote high levels of work capacity.

\section{References}

1. Dal Pai D, Krug JS, Lautet L. Psicodinâmica e saúde mental do trabalhador de enfermagem: ritmo acelerado e intensificação do prazer. Enfermagem em Foco. $2011 ; 2: 38$.

2. Dal Pai D, Lautert L. O trabalho em urgência e emergência e a sua relação com a saúde das profissionais de enfermagem. Rev. Latino-Am. Enfermagem. 2008;16:12-9.

3. Tuomi K, Ilmarinem J, Jahkola A, Katajarine L, Tulkki A. Índice de Capacidade para o Trabalho. Helsinki: Instituto de Saúde Ocupacional; 1997.

4. Franco T, Merhy, EE. Mapas analiticos: una mirada sobre la organización y sus procesos de trabajo. SaludColectiva.2009;5:181-94.

5. Silva RC, Ferreira MA. A tecnologia em saúde: uma perspectiva psicossociológica aplicada ao cuidado de enfermagem. Esc Anna Nery. [periódico na Internet]. mar 2009 [acesso 9 mar 2011];13(1):169-73.
6. Pires D. A enfermagem enquanto disciplina, profissão e trabalho. RevBrasEnferm. [periódico na Internet]. out 2009 [acesso 15 nov 2011] ; 62(5):739-44.

7. Santana VS Saúde do trabalhador no Brasil: pesquisa na pós-graduação. Rev Saúde Pública. [periódico na Internet]. ago 2006 [acesso 9 mar 2011];40(spe):101-11.

8. Callegari-Jacques SM. Bioestatística: princípios e aplicações. Porto Alegre: Artmed; 2003.

9. Hair JF . Preparação para uma análise multivariada. In: Hair JF, Anderson RE, Tatham RL, Black WC. Análise multivariada de dados. $5^{a}$ ed. Porto Alegre: Bookman; 2005. p. 56-60.

10. Duran ECM, Cocco MIM. Capacidade para o trabalho entre trabalhadores de enfermagem do pronto-socorro de um hospital universitário. Rev. Latino-Am. Enfermagem. jan-fev 2004;12(1):43-9.

11. Tuomi K, Ilmarinen J, Seitsamo J, Huuhtanen $P$, Martikainen $\mathrm{R}$, Nygård $\mathrm{C}-\mathrm{H}$, et al. Summary of the Finnish research project (1981-1992) to promote the health and work ability of aging workers. Scand J WorkEnviron Health. 1997;23(Suppl 1):66-71.

12. Cotrim G. Fundamentos da Filosofia: História e grandes temas: 15.ed. São Paulo: Saraiva; 2002. 336 p.

13. Souza SBC, Bernardi IK, Catalan VM, Teixeira MG, Mello DB, Lautert L. Cronotipo, trabalho em turnos e acidentes no trabalho. In: Anais do $12^{\circ}$ Colóquio Panamericano de Investigación en Enfermería, 2010, Florianópolis. Florianópolis: Universidade Federal de Santa Catarina; 2010. p. 1-3.

14. Martins MM. Qualidade de vida e capacidade para o trabalho dos profissionais de enfermagem no trabalho em turnos. [Dissertação de Mestrado em Engenharia de Produção]. Florianópolis: Universidade Federal de Santa Catarina; 2002. 85 p.

15. Peltomäki $\mathrm{P}$, Hüsman K. Occupational health services and maintenance of work ability at workplaces. ArhHigRadaToksikol. 2002;53:263-74

16. Tuomi I. Work, technology, and competence: the concept of work, and learning. Lifelong Learn Eur. 2000;5(1):42-8.

17. Vilela RAG, Gil VFR, Iguti AM. Experiência do Programa de Saúde do Trabalhador de Piracicaba: desafios da vigilância em acidentes do trabalho. InfEpidemiol SUSjun 2001.

18. Martins MIC. A transição tecnológica na saúde: Desafio para a gestão do trabalho. Trabalho, Educação e Saúde. 2004; [acesso 03 nov 2011]; 2(2):287-310. Disponível em: http://www.revista.epsjv.fiocruz.br/upload/revistas/ r82.pdf.

19. Negeliskii C, Lautert L. Occupational Stress and Work Capacity of Nurses of a Hospital Group. Rev. Latino-Am. Enfermagem. 2011;19:606-13. 
20. Guido LA, Umann J, Stekel LMC, Linch GFC, Silva RM, Lopes LFD. Estresse, coping e estado de saúde de enfermeiros de clínica médica em um hospital universitário. CiencCuid Saúde. out-dez 2009;8(4):615-21

21. Pohjonen, T. Age-related physical fitness and the predictive values of fitness tests for work ability in home care work. J OccupEnviron Med. 2001;43:723-30.

22. Fernandes ACP, Monteiro MI. Capacidade para o trabalho entre trabalhadores de um condomínio de empresas de alta tecnologia RevBrasEnferm. 2006;59(6):752-6.

23. Martinez MC, Latorre MRDO. Fatores associados à capacidade para o trabalho de trabalhadores do setor elétrico. Cad Saúde Pública. 2009;25(4):761-72. 